\title{
The Survival Strategy of Households Affected by Tidal Floods: The Cases of Two Villages in the Pekalongan Coastal Area
}

\author{
Rika Harini ${ }^{*}, 1$, Bowo Susilo ${ }^{2}$, Tiara Sarastika ${ }^{1}$, Supriyati ${ }^{1}$, M C Satriagasa ${ }^{1}$, Rina Dwi Ariani ${ }^{1}$ \\ ${ }^{1}$ Department of Environmental Geography, Faculty of Geography, Universitas Gadjah Mada \\ ${ }^{2}$ Department of Geographic Information, Faculty of Geography, Universitas Gadjah Mada \\ *Corresponding author (e-mail: rikaharini@ugm.ac.id)
}

Received: 08 June 2017/ Accepted: 17 July 2017 / Published: 24 July 2017

\begin{abstract}
Pekalongan is one of the coastal areas of Java Island that is affected by tidal floods. Tidal floods have various impacts on the social and economic conditions of the community, thus affecting their livelihoods. The purpose of this study was to examine the impact of a tidal flood, the socioeconomic characteristics of the community and the survival approach of coastal communities in Pekalongan. This study was conducted using a purposive sampling method in two villages in Pekalongan Regency, namely Jeruksari Village and Tegaldowo Village, because these two areas are affected by tidal floods. The study was conducted by using in-depth interviews and focus group discussions (FGDs), as well as structured interviews. The structured interview sample consisted of 60 respondents who were selected at random using quota sampling. The analysis was using qualitative-descriptive and quantitative methods. The gathered data were then presented in tables, diagrams and maps. The results showed that tidal floods resulted in physical, economic, sociocultural, health, educational, and environmental damages to the communities in both villages. The majority of the community members only have an elementary school education and primarily work as labourers. There is a difference in the amount of family income between the two villages, where the average family in Jeruksari Village has a higher income (IDR 3,465,300 per month) than the average family in Tegaldowo Village with total household income of about IDR 2 million per month. The most frequently used approach for survival in both villages is what is known as the survival strategy, i.e. a strategy to meet the needs of life at a minimum level to survive.
\end{abstract}

Keywords: Survival strategy, tidal flood, Pekalongan coastal area.

\begin{abstract}
Abstrak. Pekalongan merupakan salah satu wilayah pesisir Pulau Jawa yang terdampak banjir rob. Banjir rob berdampak pada kondisi sosial dan ekonomi masyarakat, sehingga akan berpengaruh terhadap penghidupan mereka. Tujuan penelitian ini adlah untuk mengkaji dampak banjir rob, mengkaji karakteristik sosial ekonomi masyarakat dan mengkaji strategi bertahan hidup masyarakat pesisir Pekalongan. Penelitian ini dilakukan di dua desa di Kabupaten Pekalongan yaitu Desa Jeruksari dan Desa Tegaldowo. Penelitian dilakukan dengan menggunakan indept interview dan Focus Groupn Discussion (FGD) serta wawancara terstruktur terhadap 60 responden pada ke dua desa yang ditentukan secara acak. Analisis dilakukan secara deskriptif kualitatif dan kuantitatif. Data disajikan dalam bentuk tabel, diagram dan peta. Hasil penelitian menunjukkan dampak banjir rob menyebabkan kerugian secara fisik, ekonomi, sosial budaya, kesehatan, pendidikan, dan lingkungan pada masyarakat di kedua desa. Karakteristik masyarakat adalah rata-rata berpendidikan SD dan pekerjaan utama
\end{abstract}


sebagai buruh. Terdapat perbedaan jumlah pendapatan keluarga pada ke dua desa, dimana pada desa Jeruksari total pendapatan lebih tinggi (Rp. 3.465.300/bulan) dengan pendapatan total rumah tangga sekitar 2 juta perbulan. Strategi bertahan hidup yang paling banyak dilakukan di kedua desa adalah dengan strategi survival.

Kata Kunci: Strategi bertahan hidup, Banjir rob, Pesisir Pekalongan.

\section{Introduction}

Flood events are the most frequent disasters in the world (Singh and Devkota, 2015). China, the Philippines, Bangladesh, India and Thailand are all countries that are often hit by major floods. Flooding can be caused by high rainfall, but, in addition, flooding can also be from tidal sea water caused by the wind and sea tides. Tidal flooding is usually common in coastal areas.

One problem faced by coastal communities is the occurrence of tidal floods. Tidal flooding can be caused by natural factors and human factors. As a result of a tidal flood, the community will suffer losses and also the community activity will be disturbed. Tidal flooding not only happens in coastal areas of Indonesia but also in the other coastal areas of the world, such as when this happened in Miami Dade county in Florida, United States, and tidal floods have caused economic and infrastructure disruption (Union of Concerned Scientists, 2016). Even in the Florida region itself, the tidal flood is increasing in the period of 15 to 30 years in terms of in frequency, area and duration. This has caused damage to the economy, infrastructure and ecology (Union of Concerned Scientists, 2015). It is expected that in South Florida tidal floods will occur five times a year by 2030 and this will increase to ten times a year by 2040 (Miller, 2016). In addition to flooding in the Florida region, this also occurs along the eastern coast and the Gulf of the United States, which is expected to expand from year to year and cause damage to homes, public infrastructure and the environment, and cause disruption of economic activity (Dahl et al., 2017). The Boston area is also affected by tidal flooding, due to the $1.8 \mathrm{~m}$ rise in sea level in Boston, so many assets will be affected, primarily residents, land, housing, public facilities, transport infrastructure and hazardous-waste locations, so that further handling of the problem is required (Kruel, 2016).

Coastal disasters, including tidal floods, have a significant impact on coastal community life with the frequency of floods related to coastal tidal conditions (Suhelmi et al., 2014). This impact leads to various forms of adaptation within society. In other words, people need to adapt to the environment. Adjustments are made by referring to the action plans, which are to be undertaken within a certain period by a group or an individual, as self-adjustment effort (Moran, 1982). When most of the coastal areas are hit by tidal floods, the community does not have much choice. All options are expensive; they must either adapt to the existing environment or find a new place (Parker, 2017).

Utilization of resources in the form of capital is needed in an effort to maximize the mitigation of disaster risks and the achievement of sustainable development. According to Goodwin (2003), such capital includes financial capital, natural capital, physical capital, human capital and social capital. Tidal flooding occurs as a result of elevated sea height causing seawater to overflow onto the mainland. A tidal flood is a daily occurrence in coastal areas, including that of Pekalongan. Tidal flood incidents vary in their frequencies and intensities. Continuous tidal floods may have various impacts on the life of coastal communities. They mean that people cannot freely carry out community activities as well as personal activities. Tidal floods have a direct impact on the livelihood of the community. To survive and reduce the impacts of tidal floods, people need some survival approach. The strategy can be carried out jointly between 
the community, and the government agencies and private institutions in the face of a flood disaster. Every individual household has its own strategy to survive.

According to Moser (1998 in Edi 2002), a household's survival approach represents the ability of the whole family to manage the assets they own. Based on this, Moser constructs an analytical framework called the asset vulnerability framework. A household's adaptation strategy for survival can be achieved by managing family assets. This concept includes (1) labour assets, i.e. the involvement of family members (including children and/or spouse) to help with earning money; (2) human capital assets, i.e. the utilization of health status, education or skills possessed to obtain jobs; (3) productive assets, which include house, land and livestock, to help the family survive; (4) family relation assets, which utilizes extended family networks, ethnic groups and labour migration through 'remittances'; and (5) social capital assets, i.e. theutilization of localnetworks in the form of arisan (savings and loan group), and loans provided within the family process and system. These five assets can be used with three different strategies, namely (1) an active strategy, i.e. optimizing family potential, in which every family member completes his/her own activities without the help of the others, extends working hours, utilizes the potential of land around the house, etc.; (2) a passive strategy, i.e. saving family expenditure for food and non-food items; (3) a network strategy, i.e. utilizing formal networks and non-formal networks in the social environment as well as the available institutions, such as borrowing money from neighbours, borrowing from stall, utilizing a poverty alleviation programme, etc.

A different concept is proposed by Sumintarsih (2008) according to which a survival approach is measured on the basis of three components with a variety of human activities to meet their basic needs: (1) Assets, which is the ability to survive and includes natural capital, social capital, physical capital, human capital and financial capital; (2) Activity, which is the effort made by family members to support family survival through social and economic activities; and (3) Access, which is the interaction between regions to obtain services (economic means and infrastructure) to meet their life needs.

Aside from meeting the needs of life, the livelihood strategies undertaken by the community also aim to strengthen the source of a person's livelihood. White (1991 in Baiquni, 2007), divides livelihood strategies based on the socioeconomic status of the household. There are three kinds of strategy: (1) survival strategy, i.e. a strategy to meet the needs of life at a minimum level to survive; (2) consolidation strategy, i.e. a strategy to meet the needs of life that is reflected in the fulfilment of basic needs and social needs; and (3) accumulation strategy, i.e. a life-sustaining strategy to meet basic needs, social needs and capital accumulation. The three strategies are very dynamic depending on the socioeconomic conditions of the household. A household may start with a survival strategy then move to a consolidation strategy and, as its socioeconomic condition improves, it may move to the accumulation strategy.

A coastal area is an area that cannot be separated from the threat of tidal flood disasters. In the coastal areas of Pekalongan, since 2006 this region has been affected by tidal floods. The impact of the tidal floods is that they have destroyed and overhauled the sources of livelihood for society, and rob has made agricultural land into a persistent puddle of saltwater (Nisrina, 2016). Although often affected by tidal floods, people choose to stay afloat in the region. They have various strategies for survival. It is interesting to examine how people living in areas prone to tidal flood disasters are able to survive.

\section{Research Method}

This study was conducted in two villages in the coastal area of Pekalongan using the purposive sampling method. Jeruksari Village and Tegaldowo Village were chosen because these two areas are affected by tidal floods. The sample areas are adjacent to the coastal areas and areas some distance from the coast can be seen in Figure 1. The sample sites were also selected based on coastal disaster studies 
by Marfai and King (2008a), Marfai (2011) and Mardiatno et al. (2012).

This study used qualitative-descriptive and quantitative methods. The purpose of using the qualitative-descriptive method was to provide information on the impact of tidal floods, while the quantitative method was used to assess the socioeconomic characteristics and survival strategies of tidal-flood-affected communities. The community sampling was conducted using a sampling quota. The fulfilment of the number of respondents in the sample used in the study using quota sampling method was based on the expert judgment of the researchers. This study used 30 randomly selected respondents from each village so that the total sample size was 60 . The data were gathered through structured interviews, indepth interviews and focus group discussions
(FGDs). The interview data were used to assess the socioeconomic characteristics and survival strategies of the coastal communities. In order to assess the impacts of tidal floods, in-depth interviews were conducted with the Regional Disaster Management Agency (Badan Nasional Penanggulangan Bencana) (BPBD), and the Livestock and Husbandry Agriculture Agency (Dinas Peternakan Perikanan dan Kelautan) (DPPK). The coastal impacts were also examined through FGDs with village government officials, community groups, community members and community elders / community leaders. The affected flood areas were mapped in a participatory way using SPOT 5 satellite images extracted from Google Earth. By using these images, the community delineated the tidal flood affected areas in a participatory way.

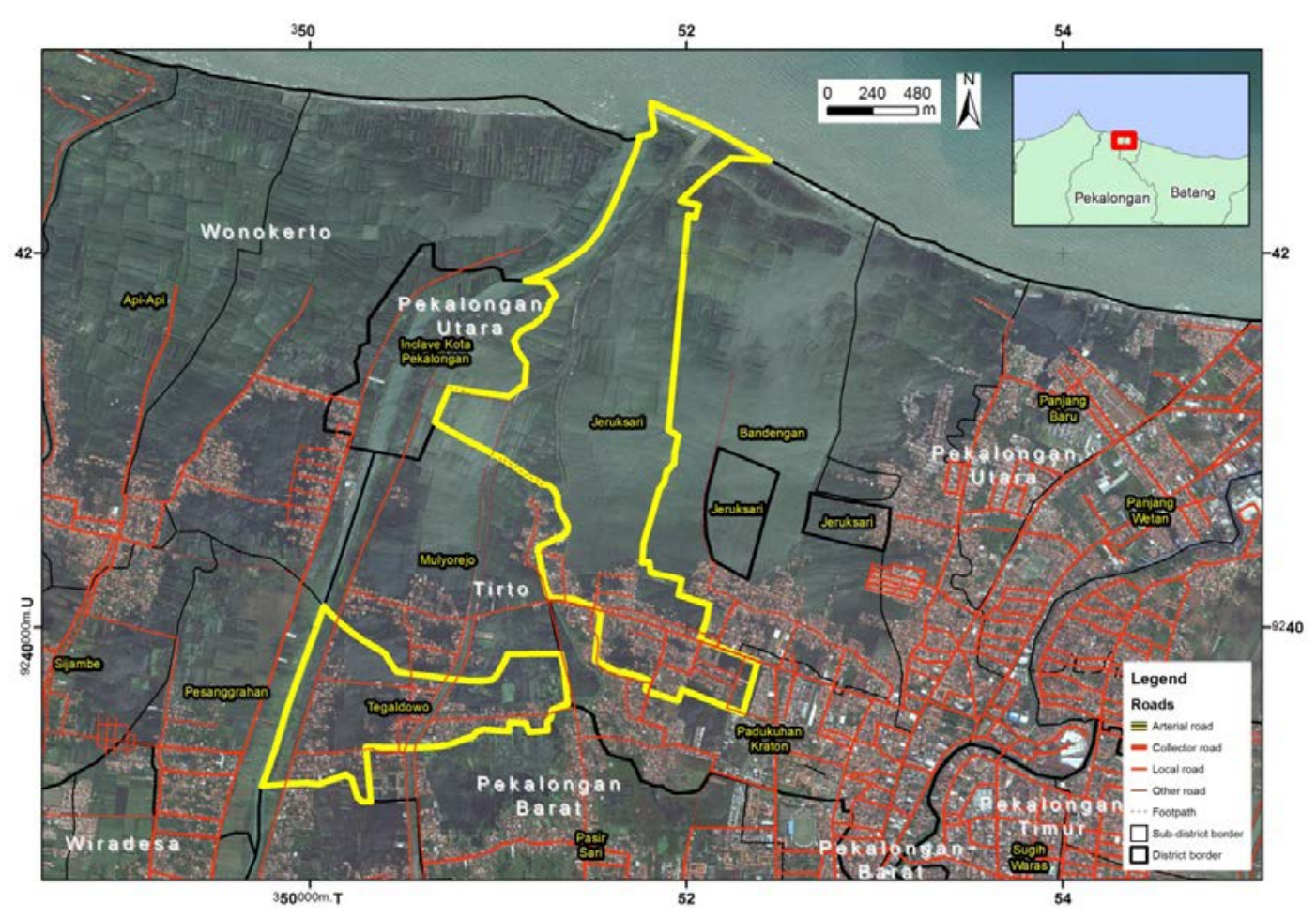

Figure 1. Map of research location

\section{Results and Discussion a. Tidal Flood Impacts}

Tidal floods in the coastal areas of Pekalongan began to occur in 2003, marked by sea water overflow into coastal ponds. In 2010, tidal floods began to inundate agricultural lands and settlements in the eastern coastal region of
Pekalongan. Tidal floods got worse during the period of 2011-2015 and culminated in 2016, which was marked by sea water inundating the whole coastal area of Pekalongan. It corresponded to the results of an interview with one of the community, who stated that "ancient sea tides did not enter into the house, but 
now they have entered until it is knee deep". The impact of tidal flooding is even across several types of land use, namely agricultural land, fish-pond land, roads and the citizens' housing, through the water and the river, presented in Figure 2. The impacts of tidal floods on the coastal areas of Pekalongan were felt in various aspects of life, including the physical, economic, sociocultural, health, education and environment aspects. Coastal communities feel threatened and suffered losses of / damage to property, farmland, ponds, buildings, roads, public facilities and economic activity due to tidal floods (Marfai, 2004).

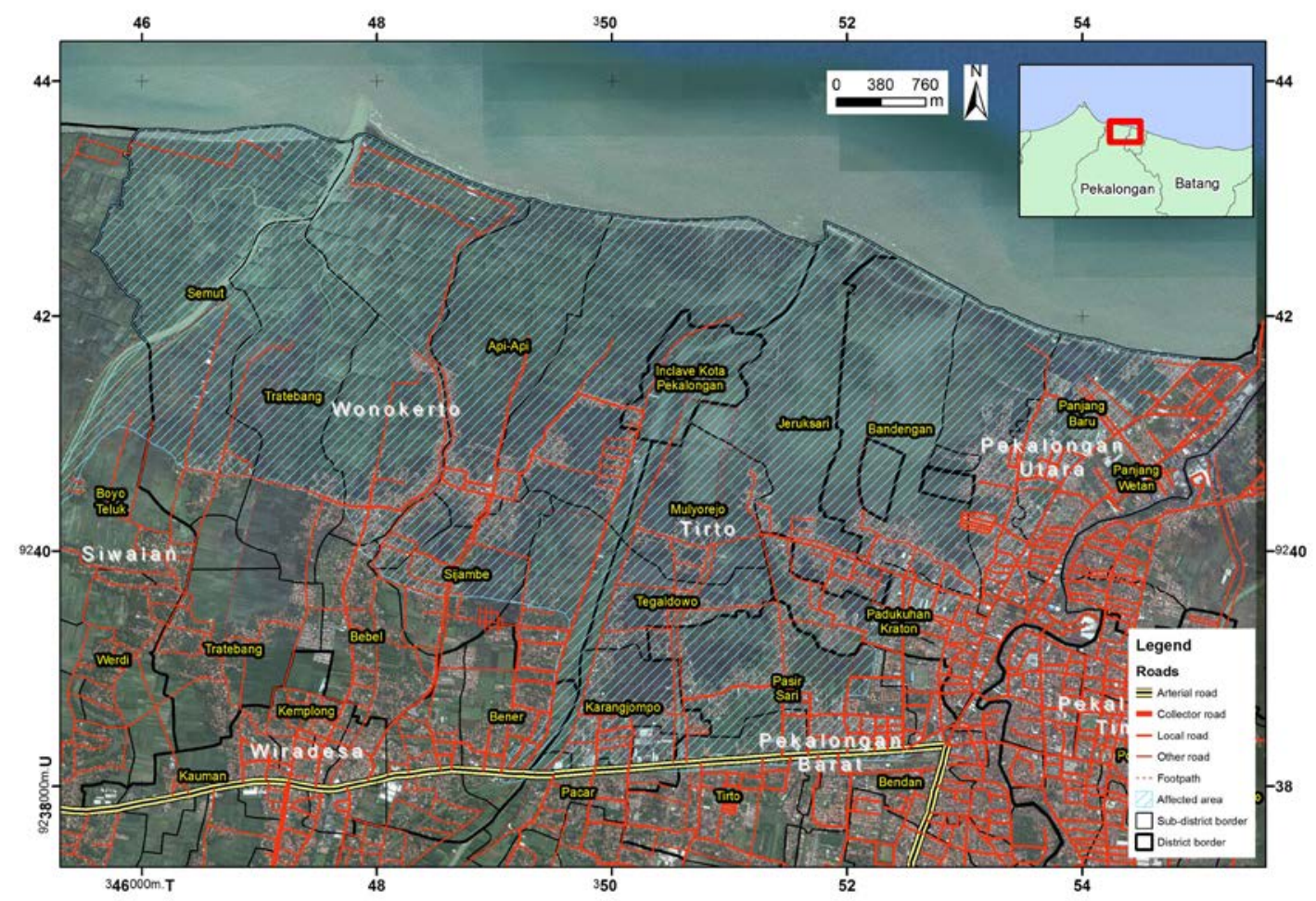

Figure 2. Pekalongan areas affected by tidal floods

The physical impacts of tidal floods include damage to residential buildings, household furniture and motor vehicles. Buildings that are inundated for long periods of time will be vulnerable and will easily collapse. Buildings such as these become uninhabitable because it would endanger the people living in them. The tidal flood water also affects household furniture belonging to the community: woodbased furnishings will be weathered, while iron- or aluminium-based furnishings will be rusted. Another physical impact is damage to motor vehicles, as their motor engines will be quickly damaged and rusted. According to one interviewee, "since the flooding, my motorcycle is broken; it was recently bought a year ago and has already started rusting". This causes huge losses to the community because the motor vehicles they use for daily mobility are quickly damaged and cost a lot to repair.

People have suffered economic losses due to tidal floods that reduced their income and increased their spending. Agricultural land and ponds, as sources of community livelihood, have been inundated, so that they are no longer productive. Fishermen have also suffered losses due to tidal floods because of the difficulties in distributing the fish they catch and in drying the fish. On the other hand, public expenditure increases as a result of the floods, including expenses for the repair of houses, goods, embankments and roads.

A new phenomenon that occurs due to tidal floods is the migration from the original occupation of farmer, both in agricultural land and farm ponds, to factory workers and 


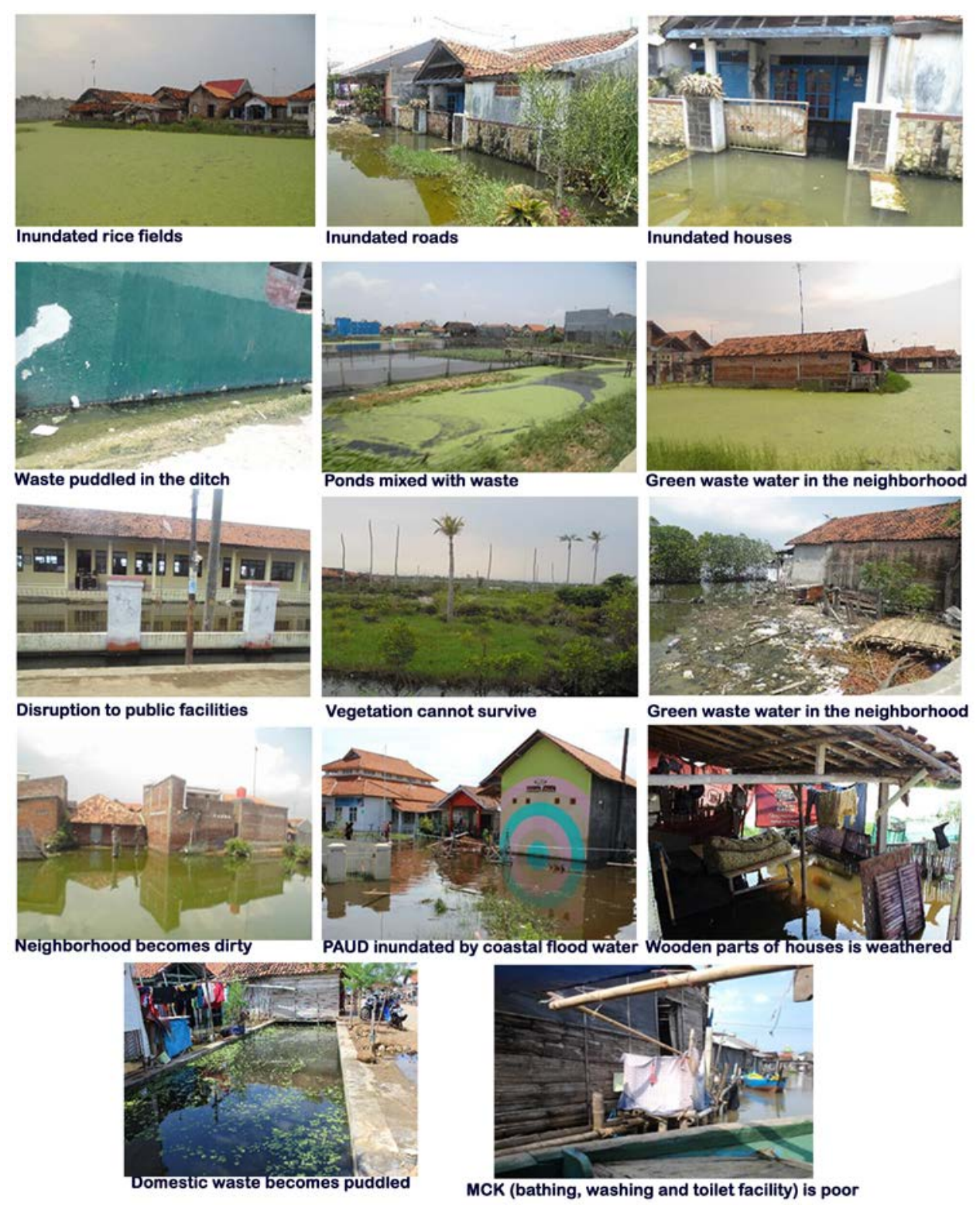

Figure 3. Impacts of tidal floods in Pekalongan coastal areas

construction workers. This is supported by data from BPS that illustrate Jeruksari Village and Tegaldowo Village have seen a change in the dominant form of work. The percentage of the people of Jeruksari Village who worked as farmers was $14.81 \%$ in 2014 and it declined to $3.41 \%$ in 2015, while there has been an increase in the percentage of people whose livelihood is from being a labourer, which was originally $43.16 \%$ in 2014 , but was $64.71 \%$ in 2015 . The same thing happened in the Tegaldowo Village indicating that the percentage of the workforce who were farmers in 2014 was $14.52 \%$ and declined to $0.78 \%$ in 2015, while there was an increase in the percentage of people who worked as labourers, which was $62.92 \%$ in 2014 and $79.89 \%$ in 2015.

Tidal floods have various impacts on the sociocultural aspects of the community as well, such as disrupted community accessibility, the cessation of public facilities, loss of public areas and increased poverty. Tidal floods greatly disrupt the accessibility of the people; water inundated roads make it difficult for people to travel, thus requiring more time and effort for travelling. Various public facilities, such as places of worship, public health centres and schools, cannot function because of the tidal flood water. Similarly, various public areas, including recreation places such as beaches 
and playing fields, are also inundated with tidal flood water. This condition may increase poverty in tidal-flood-affected areas.

The impacts of tidal floods on aspects of public health include incidents of skin diseases, diarrhoea and acute respiratory infection (infeksi saluran pernapasan akut) (ISPA). The intrusion of sea water causes groundwater to become brackish, meaning that the water salinity level increases. Therefore, the Pamsimas (provision of clean water and sanitation for the community) programme is currently carried out to meet community needs of clean water. The impact of tidal floods on the environmental aspect is in form of a lot of garbage, which results in the environment becoming dirty. Waste from households, fisheries and factories are mixed and puddled in the communities' neighbourhoods. In addition, this dirty environment creates an unpleasant smell. An overview of the various impacts of tidal flooding experienced by the community are presented in Figure 3.

Table 1. Household Characteristics of Respondents in Jeruksari Village and Tegaldowo Village in Tirto District, Pekalongan Regency

\begin{tabular}{clrr}
\hline \multirow{2}{*}{ No. } & \multicolumn{1}{c}{ Description } & Jeruksari & Tegaldowo \\
\cline { 3 - 4 } & & Average & Average \\
\hline 1 & Number of household members & 5 & 4 \\
2 & Head of household's education & Elementary school & Elementary school \\
3 & Head of household's occupation & Labourer & Labourer \\
4 & Head of household's income (IDR) & $1,282,000$ & $2,465,500$ \\
5 & Total household income (IDR) & $3,465,300$ & $2,731,100$ \\
\hline
\end{tabular}

Source: Primary Data Analysis, 2017

\section{b. The Socioeconomic Characteristics of Pekalongan Coastal Community}

The socioeconomic condition of a society characterizes the resource potential of the people residing in a region. Better socioeconomic conditions in a society reflect the higher quality or potential of human resources. The benchmark of human resource potential is characterized by the quality of human resources for health level, education level and the purchasing power of the community, which can be assessed from the average level of household income.

Table 1 shows the description of the socioeconomic characteristics in the study area, including the number of household members, level of education, types of occupation, head of household's (KRT) income and total household income. The average number of household members in Jeruksari Village is five while in Tegaldowo Village it is four. The number of household members will affect people's lives. Adult family members can help to add to the household income, while children under five or school-aged children are burdens on the family.
The average level of education of the heads of households in Jeruksari Village and Tegaldowo Village is elementary school (sekolah dasar) (SD) level. This indicates that the participation of Pekalongan coastal communities in education is still relatively low. This condition will inevitably affect people's occupation types and thus will directly affect their income level. This condition is in accordance with the results of Wasak's (2012) research, which demonstrates that the average level of education of coastal communities in the North Minahasa region is primary school, which was attained by $63.3 \%$ of the population. This indicates that the level of community education is still low. Coastal communities prefer fishing as a way to add to household income rather than pursuing education. The response of coastal communities to formal education and the free education programmes provided by the government is still low; this is influenced by mindset, community culture and economic demands (Kurniawan, 2016).

The survey results show that the occupation of the majority of heads of household in Jeruksari and Tegaldowo Villages is as a labourer either 
as factory worker or construction worker. Most of them do not work in Jeruksari Village and Tegaldowo Village. Rather they work in some other villages or in the city of Pekalongan, which provides more job opportunities. Historically, prior to the continuous flooding, some people in Jeruksari Village and Tegaldowo Village had paddy fields. However, due to tidal floods the rice fields become unfeasible to plant and eventually become ponds. However, these ponds are currently threatened by the higher tidal floods so that the farmers have suffered substantial losses. People who were previously rice farmers had turned into fishermen or pond farmers, and today most of them work as factory workers or construction workers.

There is a difference in the average income of the heads of household in Jeruksari Village and Tegaldowo Village. The average income of the heads of household in Jeruksari Village is lower (IDR 1,282,000) than that of Tegaldowo Village (IDR 2,465,500). The income of the heads of households in Jeruksari Village is lower than the regional minimum wage (upah minimum regional) (UMR) of Pekalongan Regency. As of year 2017, the UMR value of Pekalongan Regency is IDR 1,583,697.

Household income is an indicator of the household economic level. The source of household income includes basic income and side income. The main income is sourced from the head of household's income, while the side income is income from other household members. The help of other household members to meet the living needs of coastal communities, especially those affected by tidal floods, is essential. The results illustrate that there is an increase in the average household income among those households whose total income is added to by family members other than the head of the household, compared to that of households that rely on the head of the household's income only. The average household income in Jeruksari Village is higher than that of Tegaldowo Village. The average household income in Jeruksari Village is IDR 3,465,300 per month, whilein Tegaldowo Village it is IDR 2,731,100 per month. This condition indicates that low income communities tend to involve family members other than the head of the household to increase household income in order to meet their needs. In communities affected by tidal floods, the income they earn is not only used to provide for daily living but part of it is used to prevent water from entering the house and surrounding environment. It takes a considerable cost to raise the house or to make a dike in front of the house. Government assistance programmes are generally used for public facilities' improvements in order to mitigate the impacts of tidal floods.

The socioeconomic condition of the coastal community is that it is economically marginalized, so an approach is needed to improve their standard of living. In order for the fishing community to survive in the unity of the environment in the midst of the global economy, it is necessary to prioritize the values of social identity and social capital (Prihandoko et al., 2012).

\section{c. The Survival Approach of Pekalongan Community}

The tidal floods that occur in Pekalongan coastal areas, especially in Jeruksari Village and Tegaldowo Village, affect the livelihood of the community. People must adapt to the environmental conditions effected by the flood. The adaptation is not only required in terms of household activities but also in society (Harini et al., 2016). People develop strategies to adapt, both as individual households and as a community. As an individual household, among other things, they have to put things in a higher place, raise the house, make a dike in front of the house, heighten the pond embankment and install a net. The strategy undertaken as a community is to elevate the road independently, clean the ditches, dredge the river, and form special groups of fishermen and groups of mangroves. The government and private sector provide assistance to the community, among others, with the creation of Pamsimas programmes to meet clean water needs, construct coastal embankments, plant mangroves, build geotubes and coastal drainage, heighten roads, construct housing and relocate the population to safer areas. In 
line with Konsiega's (2006) study, people in Burkina Faso implemented a survival approach by leaving their territory for the Côte d'Ivoire. This is done because of the scarcity of natural resources that the people needed to survive. The reason for their movement was to get job in order to survive. The results of the research of Putra and Handayani (2013) reveal the form of adaptation undergone by the coastal community of Semarang City in the face of tidal floods: the elevation of buildings and the floor of houses, the repair and elevation of road, the planting and cultivation of mangroves, and making embankments.

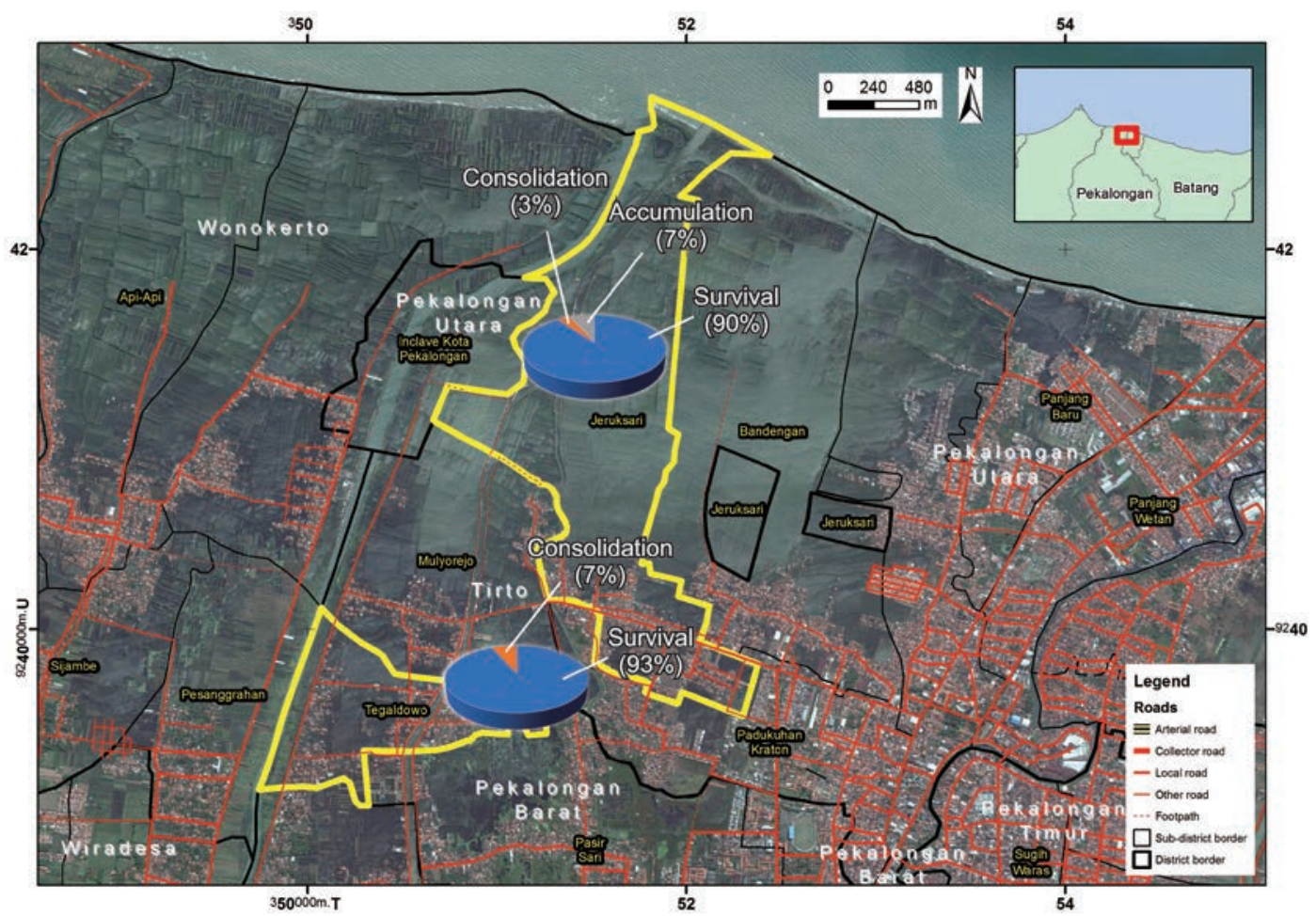

Figure 4. The survival approaches of Pekalongan's communities

The occurrence of tidal floods directly affects the survival of the Jeruksari Village and Tegaldowo Village communities. People need to implement a survival approach. The survival approach in this study includes all the means used to meet basic needs (Kaeksi and Umrotun, 2002). According to the socioeconomic status, as measured by the assets, access and activities owned by each household, the possible households' survival approaches can be divided into three. The three strategies are the survival strategy, consolidation strategy and accumulation strategy (White, 1991). As shown in Figure 4, the results of this study indicate that many different survival approaches are implemented by households in both villages: in Jeruksari Village $90 \%$ of households implemented a survival strategy, while
$3.33 \%$ and $6.67 \%$, respectively, implemented a consolidation strategy and accumulation strategy. The survival strategy is a safety and stability strategy that is the minimal strategy for people to survive. This strategy is applied only to meet the needs of everyday life, especially the need for food. In fulfilling these basic needs, some of the methods used by households involve household members other than the head of household earning money to meet the needs of life or saving household expenditures on either food or non-food items, or both. The survival strategy undertaken by the people in Pekalongan coastal areas is conducted by saving on non-food expenditure, especially expenditure for health purposes. The accumulation strategy is achieved by improving the education of household members. 
The households' survival approaches in Tegaldowo Village are not much different from those in Jeruksari Village, which is $93.33 \%$ have a survival strategy and $6.67 \%$ have a consolidation strategy; no household implemented an accumulation strategy. A consolidation strategy is a strategy undertaken by middle-class people that prioritize the security and stability of income they get from processing their resources. In this case, the household is not only able to meet the family's needs but also able to meet social needs (White, 1991). This can be done by finding a side job or utilizing resources owned through involving family members as labour. The coastal communities of Pekalongan's consolidation strategy is through having additional work and involving household members working to increase households' incomes. As stated by Wekke (2015), strategies for survival can be implemented by diversifying into various types of businesses, involving the whole family, saving on food and borrowing money from neighbours. Farmers in Belgium also do the same thing to survive. They diversify their jobs by finding jobs outside of agriculture. This is the easiest strategy to access because it can increase household income as well as maintain their agricultural activities (Meert et al., 2005). The accumulation strategy is implemented by improving the education of family members.

The community's survival approaches implemented in two villages in Pekalongan Regency is in line with the research conducted by Marfai and Hizbaron (2011), which describes how the adaptation by communities in coastal areas of Semarang varies depending on the economic conditions and the level of public knowledge. The coastal communities of Pekalongan's ability to adapt to tidal floods relates to several components, consisting of the ability to repair houses, the ability to improve infrastructure, the availability of technology, the availability of institutions, economic capacity, the sources of funds used to handle tidal floods and the availability of economic capital (Purifyningtyas and Wijaya, 2016).

\section{Conclusions}

Jeruksari Village and Tegaldowo Village are examples of villages affected by tidal floods in Pekalongan Regency. Tidal floods affect almost all coastal areas of Pekalongan. The impacts caused by tidal floods include physical, economic, sociocultural, health, education and environmental aspects. Many residential areas have been damaged and even drowned by rob. The lost agricultural lands and ponds also directly affect education activities, and have led to various health and environmental sanitation issues. Similar impacts were also found in the two study villages. The socioeconomic characteristics of the population in the two villages are almost the same. Most people only have a primary school education, and work as factory workers or construction workers. Generally speaking, the average income level is not too low (above IDR 1 million) per month. The approach implemented by most people in both villages to survive is the survival strategy. People aim to meet their basic needs to survive. A consolidation strategy is sometimes implemented by involving family members other than the head of household in earning money. An accumulation strategy may also be implemented by utilizing a kinship network and capital ownership.

\section{Acknowledgements}

Theauthors would like to express gratitude to the people in the Pekalongan coastal areas, especially those in Jeruksari Village and Tegaldowo Village, local government officials, and all parties who participated in this study; and to the Ministry of Research and Technology of Higher Education (Kemenristekdikti) and the Institute for Research and Community Service (Lembaga Penelitian dan Pengabdian Kepada Masyarakat) (LPPM) of Universitas Gadjah Mada (UGM) for providing financial support through the Grant of Decentralization of Excellence Research of Higher Education (Penelitian Unggulan Perguruan Tinggi) (PUPT). 


\section{References}

Baiquni, M. (2007). Strategi Penghidupan di Masa Krisis. Idea Media, Yogyakarta

Badan Pusat Statistik Kabupaten Pekalongan (2015). Kecamatan Tirto Dalam Angka Tahun 2015. Pekalongan : Badan Pusat statistik

Badan Pusat Statistik Kabupaten Pekalongan (2016). Kecamatan Tirto Dalam Angka Tahun 2016. Pekalongan : Badan Pusat statistik

Dahl, K. A., Fitzpatrick, M., Siegfried, F., Spanger, E. (2017). Sea Level Drives Increased Tidal Flooding Frequency at Tide Gauges Along The U.S. East and Gulf Coast : Projections For 2030 and 2045. PLoS ONE, 12 (2): e0170949. doi:10.1371/journal.pone.0170949

Edi, S. (2002). Coping Strategies Dan Keberfungsian Sosial: Mengembangkan Pendekatan Pekerjaan Sosial Dalam Mengkaji Dan Menangani Kemiskinan. Seminar "Kemiskinan dan Keberfungsian Sosial: Merancang-Kembangkan Program Pembangunan Kesejahteraan Sosial yang Bernuansa Pekerjaan Sosial" Selasa 17 Desember 2002 at Institut Pertanian Bogor.

Goodwin, N.R. (2003). Five kinds of capital: Useful concepts for sustainable development. Tufts University Medford, MA.

Harini, R., Rahayu, E., Sarastika, T. (2016). Adaptation Strategy Communities Facing Coastal Hazard in Semarang Coastal Area. Journal of Education and Social Science, 4. ISSN 2289-9855. Retrieved from http://jesoc.com/issue/volume-4-june-2016-issue-2/.

Harini, R., Giyarsih, S. R., Rahayu, E., Sarastika, T. (2016). Adaptation Strategy Communities Facing Coastal Hazard in Demak Coastal Area. Proceeding The 8th International Graduate Students and Scholars, Conference in Indonesia (IGSSCI). 26-27 Oktober 2016. The Graduate School of Universitas Gadjah Mada Yogyakarta

Kaeksi, R. W., Umrotun, U. (2002). Strategi Kelangsungan Hidup Anak Jalanan di Kota Surakarta. Forum Geografi, 16 (1). Retrieved from http://journals.ums.ac.id/index.php/fg/article/ view/415

Konseiga, A. (2007). Household Migration Decisions as Survival Strategy: The Case of Burkina Faso. Journal of African Economy, 16 (2), pp. 198-233.

Kruel, S. (2016). The Impact of Sea Level Rise on Tidal Flooding in Boston, Massachusetts. Journal of Coastal Research, 32 (6), pp. 1302- 1309. https:/ / doi.org/10.2112/JCOASTRES-D-15-00100.1

Kurniawan, A., (2016). Education for Marginalized Communities as Alternative Solution on the Coastal Area. Jurnal Cendekia, 14 (2). ISSN: 1693-1505 (p) and 2477-796X (e).

Mardiatno, D., Marfai, M. A., Rahmawati, K., Tanjung, R., Sianturi, R. S., Mutiarni, Y. S. (2012). Multirisk Assesment of Coastal and River Floods in Pekalongan Utara. Cahaya Press. ISSN: 978602-19549-9-7

Marfai, M. A. (2004). Pemodelan Spasial Banjir Pasang Air Laut Studi Kasus: Pesisir Timur Semarang. Forum Geografi, 18(1), pp. 60-69. Retrieved from http://journals.ums.ac.id/ index.php/fg/article/view/599

Marfai, A., and Hizbaron, D. R. (2011). Community's Adaptive Capasity Due To Tidal flooding in Semarang Coastal City,Indonesia. Analele Universite Oradea-Seria Geografie. ISSN 14542749-ISSN 2065-1619. Year XXI No 2/2011, pp. 229-221

Marfai, M. A. and King, L. (2008a). Tidal flood management in Semarang, Indonesia. Environmental Geology, 55: 1507-1518. 
Marfai, M.A., and King L. (2008b). Potential Vulnerability Implications of Coastal Inundation due to Sea Level Rise for the Coastal Zone of Semarang City, Indonesia. Environ Geol, 54:12351245, DOI 10.1007/s00254-007-0906-4.

Marfai, M. A, Yulianto F., Hizabron D. R., Ward P., Aerts. (2009). Preliminary Assessment and Modeling the Effects of Climate Change on Potential Coastal Flood Damage in Jakarta. Joint Research Report. Vree Univ Amsterdam and Gadjah Mada univ.

Marfai, M. A., King, L, Sartohadi, J., Sudrajat, S., Budiani, S. R., and Yulianto, F. (2008). The Impact of Tidal Flooding on A Coastal Community in Semarang, Indonesia. Environmentalist, 28, pp. 237-248.

Meert H, G. Van Huylenbroeck, T. Vernimmen, M. Bourgeois, E. van Hecke. (2005). Farm household survival strategies and diversification on Marginal Farms. Journal of Rural Studies. Volume 21, Issue 1, January 2005, Pages 81-97. Elsevier

Miller, K. (2016). South Florida tidal floods could occur 10 times per year by 2040. Palm Beach Post. http:/ / www.mypalmbeachpost.com/weather/south-florida-tidal-floods-could-occurtimes-per-year 2040/qPpnaHTvEfjPOCn6OoCfjP/

Moran, E. F. (1982). Human Adaptability: An Introduction to Ecological Anthropology. Boulder, Colorado: Westview Press, Inc.

Nisrina, H. I. (2016). Rob dan Ruang Lingkup. https://indonesiana.tempo.co/ $\mathrm{read} / 88372 / 2016 / 09 / 07 /$ ina.nisrina/login diunduh 13072017

Parker, L. (2017). Sea Level Rise Will Flood Hundreds of Cities in the Near Future http://news. nationalgeographic.com/2017/07/sea-level-rise-flood-global-warming-science/

Prihandoko, S., Amri, J., Darwis, S., Gani, I. Gusti, P. P., Luky, A. and Iwan T. (2012). Kondisi Sosial Ekonomi Nelayan Artisanal di Pantai Utara Provinsi Jawa Barat. Jurnal Penyuluhan, 8 (1).

Purifyningtyas, H. Q., and Wijaya, H. B. (2016). Kajian Kapasitas Adaptasi Masyarakat Pesisir Pekalongan Terhadap Kerentanan Banjir Rob. Jurnal Wilayah dan Lingkungan, 4(2), 81-94. doi:10.14710/jwl.4.2.81-94

Putra, A. (1997). Budaya Masyarakat di Lingkungan Kawasan Industri. Kerangka Acuan (T.O.R). Direktorat Sejarah dan Nilai tradisional:

Putra D. A and Handayani, W. (2013). Kajian Bentuk Adaptasi Terhadap Banjir Dan Rob Berdasarkan Karakteristik Wilayah Dan Aktivitas Di Kelurahan Tanjung Mas. Jurnal Teknik PWK, 2 (3), pp. 786-796. Retrieved from http://ejournal-s1.undip.ac.id/index.php/pw

Saleh, E. S. (2014). Strategi Penghidupan Penduduk Sekitar Danau Limboto Provinsi Gorontalo. Laporan Akhir Penelitian Disertasi Doktor. Universitas Negeri Gorontalo

Singh. M. and Devkta, L. (2015). People's Perspective on Flood Hazard and Adaptation Strategies in the Koshi River Basin of Nepal. Nepal Development Research Institute.

Suhelmi, I. R, Achmad, F., and Triwibowo, F. H. (2014). Potential Economic Losses Due to Tidal Inundation and Flood at Semarang City. Forum Geografi, 28 (2), pp. 113-118. Retrieved from http://journals.ums.ac.id/index.php/fg/article/view/428

Sumintarsih (2008). Strategi Bertahan Hidup Penduduk di Daerah Rawan Ekologi. Jurnal Sejarah dan Budaya (Jantra), 3 (5). 
Union of Concern Scietiests (2016). Tidal Flooding ang Sea Level Rise in Miami Dade Country, Florida 2016. www.ucsusa.org/EncroachingTidesMiamiDade

Union of Concern Scietiests (2015). Encroaching Tides in the Florida Keys, 2015. www.ucsusa.org/ encroachingtidesfloridakeys

Wasak, M. (2012). Keadaan Sosial Ekonomi Masyarakat Nelayan di Desa Kinibuhutan Kecamatan Likupang barat kabupaten Minahasa Utara, Sulawesi Utara. Pacific Journal, 1 (7), pp. 1339.

Wekke, I.S, Cahaya A. (2015). Fishermen Poverty and Survival Strategy: Research on Poor Households, in Bone Indonesia.4th World Conference on Business, Economics and Management, WCBEM. Procedia Economics and Finance, 26, pp. 7 - 11.

White, B., 1991. In the shadow of agriculture: economic diversification and agrarian change in Java, 1900-1990. ISS Working Paper Series/General Series 96, 1-39. 